\title{
Government policy in giving land procurement replacement for development
}

\author{
Wahyu Prawesthi ${ }^{1}$, Meithiana Indrasari ${ }^{2}$, Basoeki Nugroho ${ }^{3}$, Nur Syamsudin ${ }^{4}$ \\ \{wahyu.prawesthi@unitomo.ac.id ${ }^{1}$, meithiana.indrasari@unitomo.ac.id ${ }^{2}$, \\ basoeki.nugroho@unitomo.ac.id\} \\ ${ }^{1,2,3}$ Dr. Soetomo University Surabaya, Indonesia \\ ${ }^{4}$ Walisongo State Islamic University Semarang, Indonesia
}

\begin{abstract}
Development activities carried out in Indonesia in general and regionally, in particular, are increasing, especially development carried out by the government for the public interest based on Law Number 2 of 2012 concerning Land Procurement for Development in the Public Interest. This is very important to understand that the development is not only done by the government itself, but for the interests of the nation, state, and society. Therefore, in the implementation of the development must be based on government policy policies in particular compensation provided to the community. Problems in providing compensation to holders of land rights or communities affected by development projects arise because of differences of opinion both based on government policies and their implementation to the community, especially holders of land rights affected by the development project.
\end{abstract}

Keywords: Government Policy, Compensation, Land Procurement

\section{Introduction}

Development developments in Indonesia are increasingly increasing. The construction activities of inputs school buildings, hospitals, markets, train stations, places of worship, bridges, the procurement of various projects for the manufacture and widening of roads and other developments require land as the main means.

The problem that then arises is how to take land belonging to the community for development projects. This indeed concerns the most controversial issue regarding land issues. On one side, the construction of land will be so urgent, while on the other hand, as a community member, it also requires land as a place of settlement and place of livelihood.

The process of providing compensation in land acquisition activities is very important because, without compensation, the development will be hampered. Compensation according to Law No. 2 of 2012 is a proper and fair replacement to the entitled parties in the land acquisition process. Non-physical losses include eliminating jobs, business fields, sources of income, and other sources of income that have an impact on decreasing one's health status. [1]

According to Ooan Sitorus and Carolina Sitepu compensation is compensation received by holders of land rights as a substitute for the value of land, including those above, which have been released or delivered.[2] In return, the principle of providing compensation must be balanced with the value of the tax, including all items contained therein, which have been released or delivered. [2]

The implementation of compensation in land acquisition activities is carried out based on the provisions of the prevailing laws and regulations, but in its implementation, despite 
changing several laws and regulations there are still some obstacles faced by the government.[3]

\section{Problem and Method}

What is the analysis of government policy in compensation for land acquisition for development in the public interest? " The method of writing this article uses the analytical method using juridical qualitative analysis methods related to government policy in providing compensation to holders of land rights. This analysis departs from norms, principles, and legislation that exist as positive legal norms which are then analyzed qualitatively by jurid, with the understanding that the results of the analysis will be realized in the form of descriptions rather than in the form of numbers.

\section{Result and Discussion}

Giving compensation can be termed as compensation, because the rights to the land including objects related to land are estimated to have been used in the implementation of land use for a public interest, and it is usually assumed that there will be parties who sacrifice to surrender land rights. land to the state for public purposes. Or another term in Presidential Decree No. 55 of 1993 as "a form of respect for land rights".

In fact, this is not always the case, the term compensation itself means a sum of money obtained by the landowner after giving up his rights or land worth an open market value plus other losses due to the release of land rights. The amount paid is not only for land taken but also other losses as a result of the acquisition. The basic principle in compensation is to place landowners affected by the acquisition in the same position after the acquisition as before [4] Therefore, in principle, a proper calculation of compensation must take into account and pay attention to three important aspects, namely, economic aspects, sociological aspects, and philosophical aspects. But throughout the history of the regulation of land acquisition in Indonesia, there has never been a calculation of the philosophical and sociological losses experienced by landowners, such as the impact of job losses and socio-cultural consequences in the new residential environment. There is no provision that shows that the provision of compensation guarantees the lives of those who lose their land rights to be better.

The next view was written by Soedjarwo Marsoem by using the term "profit change". Whereas in many cases it has often arisen where the people affected by land acquisition become victims of their standard of living do not improve, on the contrary, it is the opposite, namely down, falling down, poor then living in unfit conditions. Of course, this is not desirable because, in national development, all-natural resources and the entire Indonesian bloodshed must be utilized to the extent of the interests of the general public, not for the interests and benefits of a few people[5]. During this time, the compensation received by the landowners was limited to the physical value of their land. The replacement is limited to the multiplication of land area with the Tax Object Selling Value (NJOP) of a plot of land. The replacement value is still possible to be reduced by the power of the ruling elements who ask for rations. It can also be reversed, the replacement value can be enlarged to get a larger disbursement of state funds.[6]

Therefore, after the community experienced eviction of the land they owned, the owner had difficulty in having an equivalent piece of land. Not to mention the social losses experienced because the owner was deprived of his social life so far. In practice this kind of compensation makes landowners get a replacement that makes them suffer losses. This condition reverses in the current land period or regime. Here are also rules that allow for the 
replacement of land and underground space, buildings, plants, and objects related to land. There is also a substitution of non-physical land values that calculates the loss suffered by the owner for the loss of ownership of their land. Various models of replacement for the loss of ownership of this land are called compensation because the landowner gets a replacement that makes him feel the benefits.[7]

Based on Article 63 of the Presidential Regulation Number 99 of 2014 concerning the Second Amendment to Presidential Regulation Number 71 of 2012 concerning the Implementation of Land Procurement for Development in the Public Interest, that the determination of the amount of compensation is carried out by the Chairperson of Land Acquisition. Procurement of appraisal services is carried out in accordance with the provisions of the legislation in the field of Government Procurement of Goods and Services. In the case that the value of the procurement of services for Public Appraisers of Appraisers is above Rp. $50,000,000$ (fifty million rupiahs) then the procurement of public appraisal or appraisal services is carried out using the post-qualification method.

The provision of compensation based on policy policies that are regulated is divided into two, namely by providing compensation directly or indirectly. Direct compensation is compensation provided directly by the land acquisition committee to the rightful party after obtaining an agreement regarding the amount and form of compensation in the deliberation accompanied by the Minutes of Compensation Submission. While indirect compensation is a substitute given by the land acquisition committee to the district court.

\section{Conclusion}

Looking at the mechanism for determining the amount and form of compensation as well as the basis of reference used in determining the amount and form of compensation stipulated in Law Number 2 Year 2012 in conjunction with Presidential Regulation Number 71 of 2012 above, it is actually not much different from the provisions concerning the mechanism for determining magnitude and the form of compensation and the basis of reference used in determining the amount and form of compensation as regulated by the Head of BPN Regulation Number 03 of 2007.

\section{References}

[1] M. Zaenuddin, W. Kumorotomo, S. Saleh, and A. H. Hadna, "Praktek Otonomi Daerah di Batam: Dinamika dan Permasalahan Penerapan Kebijakan Free Trade Zone (FTZ)," Pros. Semin. Nas. CENDEKIAWAN, 2017.

[2] S. Hardianto Djanggih, "Aspek Hukum Pengadaan Tanah bagi Pelaksanaan Pembangunan untuk Kepentingan Umum," J. Pandecta, 2017.

[3] B. Directory et al., "Summary for Policymakers," in Climate Change 2013 - The Physical Science Basis, 2015.

[4] S. Kowalczyk, "Jeremy Rifkin's utopia of the economy of abundance," Kwart. Nauk o Przedsiębiorstwie, 2019.

[5] O. Winarti, "Halal Tourism in Indonesia: Does it attract only Muslim Tourists?," J. Stud. Komun., vol. 1, no. 3, pp. 232-239, 2017.

[6] S. Marsoem, W. Adi, and P. G. Manoppo, Pedoman lengkap ganti untung pengadaan tanah: memetakan solusi strategis pengembangan infrastruktur di Indonesia: dilengkapi dengan berbagai peraturan penting tentang pertanahan. ReneBook, 2015.

[7] A. Kodir and D. Susilo, "CSR dan PR: Sinergitas, Kritik, dan Diskursus Budaya Komunikasi Tanggung Jawab Perusahaan,” Surabaya CV. M-Brothers Indones., 2015. 
